\title{
Simulated herbivory and the dynamics of disease in Thalassia testudinum
}

\author{
Justin W. Bowles*, Susan S. Bell \\ Department of Biology, University of South Florida, Tampa, Florida 33620-5200, USA
}

\begin{abstract}
An experiment was conducted in a Thalassia testudinum bed in SW Florida to examine the effect of simulated green turtle Chelonia mydas L. herbivory on the intensity of infection by Labyrinthula, which causes wasting disease in seagrass. Four pairs of $4.0 \mathrm{~m}^{2}$ plots were established at the site, with each pair containing one plot subjected to simulated herbivory and the other serving as an unmanipulated control. Labyrinthula infection appeared abruptly during April, reached maximum levels in May, and decreased to zero by September 2002. In plots subjected to simulated herbivory, clipped seagrass blades were more likely to be infected than new blades emerging from clipped short shoots. Three months after clipping, disease levels in the new blades were not significantly different between simulated herbivory and control plots. These results suggest sea turtle herbivory is not likely to reduce disease levels in T. testudinum.
\end{abstract}

KEY WORDS: Florida $\cdot$ Herbivory $\cdot$ Labyrinthula $\cdot$ Seagrass $\cdot$ Thalassia testudinum $\cdot$ Wasting disease

\section{INTRODUCTION}

Wasting disease, attributed to infection by a parasitic protist of the genus Labyrinthula (Renn 1935, Young 1943, Short et al. 1987, Muehlstein et al. 1988, 1991), nearly eradicated the seagrass Zostera marina L. populations in the 1930s (Peterson 1933, Taylor 1933, see also De Jonge \& Ruiter 1996). An undescribed Labyrinthula has also been suggested to play a role in the die-off of approximately 4000 ha of a subtropical seagrass, Thalassia testudinum Banks ex König, in Florida Bay (Robblee et al. 1991, Zieman et al. 1999). Until the Florida Bay die-off, wasting disease had been a phenomenon reported to affect only Z. marina.

Jackson et al. (2001) described a potential cause for the prevalence of Labyrinthula infection and the occurrence of Thalassia testudinum die-off in Florida Bay. They suggested that the severe depletion of the green turtle Chelonia mydas L., by over-fishing, increased the prevalence of Labyrinthula infection in T. testudinum in the region. Green turtles preferentially feed on T. testudinum by cropping seagrass shoots a few centimeters above the surface of the substrate, allowing the blades above the cropped region to drift away (Bjorndal 1980, Thayer et al. 1982). Turtles return to established grazing plots to consume new growth from previously grazed shoots (Bjorndal 1980, Ogden 1980), actively removing older, outer blades where necrotic Labyrinthula lesions are commonly found. It has been proposed that, historically, green turtles were so abundant that their grazing plots often converged, allowing some $T$. testudinum beds to be completely cropped (see Williams 1988, Jackson 2001, Jackson et al. 2001). In turn, green turtle grazing activity may have helped maintain healthy $T$. testudinum beds by periodically removing diseased seagrass blades. Moreover, Jackson et al. (2001) argued that if green turtle herbivory was a major factor controlling wasting disease in $T$. testudinum, then the extirpation of the green turtle from Florida Bay may have allowed Labyrinthula infection to become more ubiquitous in recent times, and cause seagrass die-off. However, experimental evidence supporting such a link between herbivory and disease levels in T. testudinum has yet to be obtained. 
A population of Thalassia testudinum was located in Pine Island Sound in SW Florida, where Labyrinthula infection was widespread. Here we describe an experiment conducted at this seagrass site designed to answer 2 main questions about disease in T. testudinum and its possible links with herbivory: (1) What are the temporal dynamics of Labyrinthula infection levels in T. testudinum, and (2) Does simulated herbivory decrease the extent of Labyrinthula infection in T. testudinum?

\section{MATERIALS AND METHODS}

Site description. The experiment was conducted in a monospecific bed of Thalassia testudinum in Pine Island Sound $\left(82^{\circ} 10.105^{\prime} \mathrm{N}, 26^{\circ} 38.982^{\prime} \mathrm{W}\right)$. Pine Island Sound is characterized by salinity ranging from 20 to $32 \mathrm{psu}$ with a temperature range typically 17 to $30^{\circ} \mathrm{C}$. The mean depth across the site is approximately $1 \mathrm{~m}$. Dense T. testudinum beds (320 to 416 shoots $\mathrm{m}^{-2}$ ) dominate the subtidal landscape. Necrotic lesions caused by Labyrinthula were initially observed at the study site in the summer of 2001, but were not apparent from August 2001 through March 2002 (see Bowles 2003). Labyrinthula appeared again in the late spring and summer of 2002, when the experiment was conducted.

Experimental design. Four treatment arrays were constructed at the site adjacent to one another, each array containing a pair of $2 \times 2 \mathrm{~m}$ plots. One plot within each array was randomly assigned to serve as the clipped, simulated herbivory plot; the other served as a paired control (i.e. no manipulation). In plots chosen for the simulated herbivory manipulation, all Thalassia testudinum shoots were clipped 2 to $4 \mathrm{~cm}$ above the sediment using large, serrated scissors. As blades of T. testudinum are positively buoyant, due to gas-filled lacunae located within the blade, they float up from shoots as they are clipped and are carried away by tidal currents. To prevent cross contamination between plots, separate pairs of scissors were used in each experimental plot. The plots were clipped once on April 28, 2002, and then allowed to grow back. Additionally, scissors were carefully passed through the seagrass shoots in control plots without severing any blades, to imitate their use in simulated herbivory plots.

Each plot was surrounded by a $0.5 \mathrm{~m}$ clipped buffer zone to minimize physical contact between shoots inside and outside of plots. The buffer zones were maintained by clipping during visits to the site every 2 to $4 \mathrm{wk}$. Given that blade-to-blade contact is thought to be the mode of Labyrinthula transmission in seagrasses (Burdick et al. 1993), the buffer zones served to prevent Labyrinthula spreading among the plots through intact shoots.
To prevent physiological integration between shoots inside and outside of the plots, rhizomes were severed around the perimeter of each plot using a spade (e.g. Tomasko \& Dawes 1989). Due to the slow rate of rhizome elongation in T. testudinum (Zieman 1976), and the short duration of this experiment, the rhizomes were severed only once at the beginning of the experiment.

Monitoring and data analysis. The site was visited 6 times following the initial experimental manipulation on April 28, 2002. During each visit to the site, shoot density was determined in each $4.0 \mathrm{~m}^{2}$ plot by counting all Thalassia testudinum shoots in five $0.25 \mathrm{~m}^{2}$ quadrats placed haphazardly within each plot. Five subsamples of shoots were randomly collected from each plot, and transported back to the laboratory on ice for analysis.

In the laboratory, emergent blades, comprising new growth arising from the basal meristem, were identified by their round tips. Epiphytes were gently scraped away from each seagrass blade using a glass microscope slide to gain an unimpeded view of the surface of the blade. Using both blade length and position, the relative age of each blade on a shoot was recorded (i.e. the shortest, innermost blades are the youngest, and age increases with increasing blade length) (Tomlinson 1974, Hily et al. 2002). Because Labyrinthula infection is commonly found on older seagrass blades, and not typically on young blades, it was necessary to identify the relative age of seagrass blades; abundant infection in young blades may indicate that shoot mortality will soon follow (Burdick et al. 1993). The percent cover of Labyrinthula lesions was visually estimated to determine the extent of infection on each seagrass blade. The darkened, splotchy and linear lesions created by Labyrinthula on seagrass blades were easily identified. To verify the presence of Labyrinthula in each lesion, a small piece of seagrass tissue was excised from each necrotic lesion, placed cut side up onto a microscope slide and suspended in a drop of seawater. The presence of spindle-shaped Labyrinthula cells were verified in infected tissue using a compound light microscope at $400 \times$ magnification, without the aid of staining. Samples were screened within $48 \mathrm{~h}$ of being collected, and were kept on ice during this storage period.

A wasting index (WI) was calculated by averaging the estimated percentage of lesion cover of the most infected seagrass blade per shoot over all shoots (Burdick et al. 1993). Specifically, the index was calculated based upon identification of the seagrass blade with the largest estimated lesion coverage on each shoot and averaging these values over the total number of shoots in the sample.

A meaningful comparison of WI between treatment and control was only possible following the senescence 
of clipped blades from clipped shoots. Because the surface area of blades that had been clipped was always less than comparable intact blades, even small Labyrinthula lesions would be assigned values of high percent cover on clipped blades. Three months after clipping, clipped blades were no longer evident in plots subjected to simulated herbivory (i.e. senescence was observed), and disease levels remained sufficiently high for a statistical comparison to be warranted. A paired $t$-test was used to test the effect of simulated herbivory on WI 3 mo after clipping. After July 24, 2002, disease levels were too low for a comparison of WI between treatments to be conducted.

\section{RESULTS}

Symptoms of Labyrinthula infection appeared abruptly in Thalassia testudinum beds at the study site during April 2002 (Fig. 1); there was no record of disease in the area from September 2001 to March 2002. A steady decline in the abundance of the pathogen was observed following May 2002, and after August 24, 2002, only trace amounts of infection were evident (Fig. 1). The onset of Labyrinthula infection coincided with flowering, with flowering shoots of T. testudinum being relatively common at the site in April 2002 (4 to 5 flowering shoots $\mathrm{m}^{-2}$ ).

Shoot density of Thalassia testudinum ranged from 320 to 416 shoots $\mathrm{m}^{-2}$ in control plots. The maximum value was recorded on May 12, 2003, with an overall decreasing trend over the course of the study (Fig. 2). No bare areas devoid of seagrass, characteristic of dieoff (Robblee et al. 1991), were found at the site.

Thalassia testudinum blades, clipped during the manipulation, began to exhibit lesions caused by Labyrinthula infection at the distal, cut end of the blade. One month following the clipping manipulation, on May 28, 2002, nearly all (85\%) clipped T. testudinum blades were infected, and the following week, on June 8 , all remaining clipped blades examined $(\mathrm{n}=26)$ were infected (Table 1). On all clipped blades examined, Labyrinthula infection appeared to spread from the severed end of the seagrass blade towards its base.

On May 28, 2002, new blades in simulated herbivory plots, which had arisen from the basal meristem, were free from infection, even while growing in close proximity to clipped blades characterized by an $85 \%$ incidence of infection (Table 1). By June 8, 2002, small Labyrinthula lesions were noted on $20 \%$ of the youngest new blades, but none were recorded on the second age class of new blades (Blade 2), while all adjacent clipped blades on these same shoots were infected. Thalassia testudinum shoots in control plots maintained Labyrinthula infection over this time

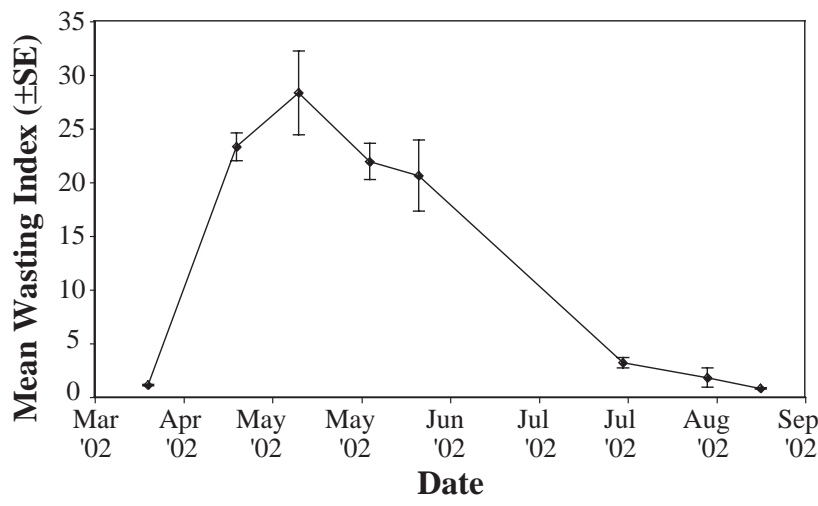

Fig. 1. Labyrinthula infection of Thalassia testudinum. Mean wasting index as an indicator of infection in $4.0 \mathrm{~m}^{2}$ control plots $(\mathrm{n}=4)$ in Pine Island Sound, Florida (USA), April to August 2002. Wasting index is calculated by identifying the seagrass blade with the largest estimated lesion coverage on each short shoot and averaging these values for all short shoots in the sample

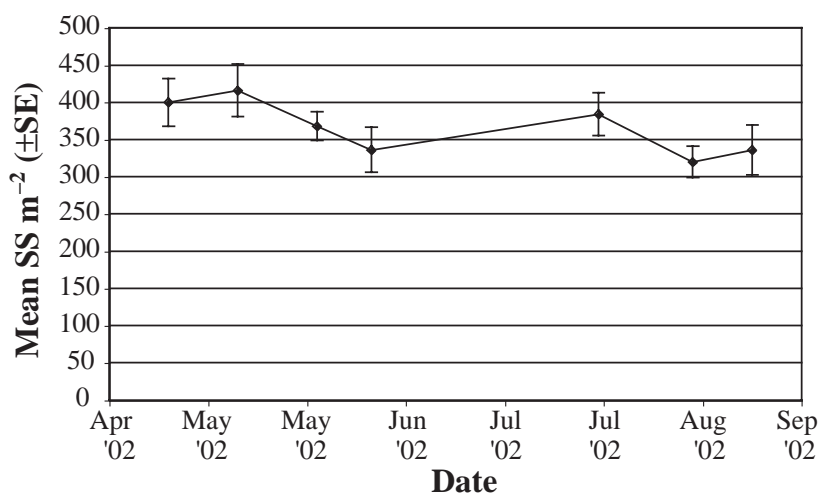

Fig. 2. Thalassia testudinum. Mean short shoot (SS) density $\left(\mathrm{m}^{-2}\right) \pm \mathrm{SE}$ in control plots $(\mathrm{n}=4)$

period (Table 1). The lesions observed on both clipped and intact blades were identical, with the same linear shape and blackened, necrotic tissue. Three months after clipping, when all clipped blades had been lost due to natural senescence, disease levels were not significantly different between simulated herbivory and control plots (paired $t$-test, $t_{3}=0.454, \mathrm{p}=0.681$ ) (Fig. 3).

\section{DISCUSSION}

In 2002, the duration of Labyrinthula infection in this population of Thalassia testudinum was approximately 12 wk between April and July, and the onset of infection was rapid. It was not related to any die-off, although the WI measured on April 28, 2002 (23.3 \pm 1.3), was comparable to values exhibited by Zostera 
Table 1. Thalassia testudinum infected by Labyrinthula. Percentage of blades infected in simulated herbivory and control plots. Five short shoots were collected on each date from plots $(n=4)$. Blades from each short shoot are numbered in increasing order from youngest to oldest (rank order by length), and classified as either clipped or emergent. Unclipped seagrass blades with intact, rounded tips are considered emergent blades. As older blades are less common on shoots, values for Blades 3, 4, and 5 are pooled together for ease of reporting (-: no blades present)

\begin{tabular}{|c|c|c|c|c|c|c|}
\hline \multirow[b]{2}{*}{ Blade: } & \multicolumn{3}{|c|}{$\begin{array}{c}\text { Simulated } \\
\text { herbivory plots }\end{array}$} & \multicolumn{3}{|c|}{$\begin{array}{l}\text { Control } \\
\text { plots }\end{array}$} \\
\hline & 1 & 2 & $3,4,5$ & 1 & 2 & $3,4,5$ \\
\hline \multicolumn{7}{|l|}{ May 28, 2002} \\
\hline $\begin{array}{l}\text { Clipped blades (total } \\
\text { number examined) }\end{array}$ & 8 & 19 & 16 & - & - & - \\
\hline $\begin{array}{l}\text { Percent clipped } \\
\text { blades infected }\end{array}$ & 100 & 85 & 92 & - & - & - \\
\hline $\begin{array}{l}\text { Emergent blades (total } \\
\text { number emergent } \\
\text { blades examined) }\end{array}$ & 11 & - & - & 20 & 20 & 16 \\
\hline $\begin{array}{l}\text { Percent emergent } \\
\text { blades infected }\end{array}$ & 0 & - & - & 20 & 80 & 81 \\
\hline \multicolumn{7}{|l|}{ June 8, 2002} \\
\hline $\begin{array}{l}\text { Clipped blades (total } \\
\text { number examined) }\end{array}$ & - & 10 & 16 & - & - & - \\
\hline $\begin{array}{l}\text { Percent clipped } \\
\text { blades infected }\end{array}$ & - & 100 & 100 & - & - & - \\
\hline $\begin{array}{l}\text { Emergent blades (total } \\
\text { number emergent } \\
\text { blades examined) }\end{array}$ & 15 & 5 & - & 15 & 15 & 12 \\
\hline $\begin{array}{l}\text { Percent emergent } \\
\text { blades infected }\end{array}$ & 20 & 0 & - & 6 & 47 & 92 \\
\hline
\end{tabular}

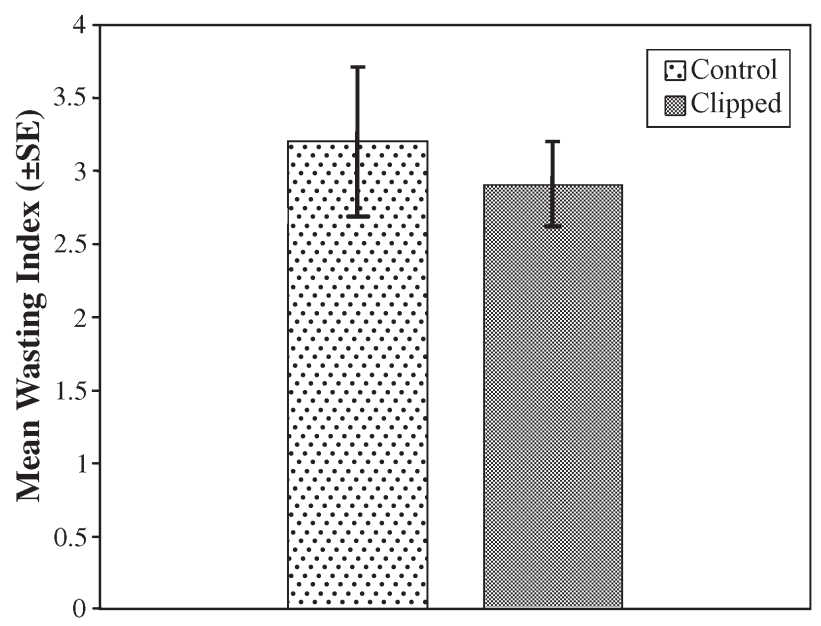

Fig. 3. Labyrinthula infection of Thalassia testudinum. Mean wasting index \pm SE in control and simulated herbivory plots on July 24,2002 , following the senescence of clipped blades from defoliated short shoots. There was no significant difference in wasting index (paired $t$-test, $t_{3}=0.454, \mathrm{p}=0.681$ ) marina populations in the NE United States experiencing wasting disease and seagrass mortality (Short et al. 1986, Burdick et al. 1993). After August 24, 2002, only trace amounts of infection could be found. These findings agree with those of Meyers (1968), who documented a similar temporal pattern of Labyrinthula occurrence in T. testudinum in Biscayne Bay, Florida. The temporal pattern of infection at the Pine Island site appears to differ from disease dynamics in Florida Bay, however, where Labyrinthula infection typically begins in August and persists through the fall (M. O. Hall pers. comm.). The factors leading to the differential onset and duration of infection on the same species of seagrass in the 2 locales are not known. However, substantial levels of infection were maintained for several months in both cases.

One month following the clipping manipulation in simulated herbivory plots, Labyrinthula lesions were observed forming at the distal, severed ends of Thalassia testudinum blades. Jackson et al. (2001) predicted that the removal of infected blades by green turtle herbivory would reduce disease levels among grazed shoots. This, however, was not observed. Instead, the frequency of occurrence of Labyrinthula lesions increased to $100 \%$ between May and early June 2002 among clipped blades remaining on clipped shoots (Table 1). In addition, diseased, clipped blades remained on clipped shoots until their senescence, prolonging the uniform presence of Labyrinthula in simulated herbivory plots. Labyrinthula infection was maintained (WI > 20) concurrently in control plots. These findings suggest that herbivory may not bring about reduced levels of disease at the site.

Among clipped blades, the presence of infection was consistent from blade to blade, and by June 8, 2002, all clipped blades exhibited necrotic lesions containing Labyrinthula. This pattern contrasts with what was seen in intact, unclipped seagrass blades; consistent amounts of infection among blades within a shoot is generally not the rule. Even when levels of infection were high in control plots, some blades escaped infection (J. W. Bowles pers. obs.).

Evidence suggests that direct blade-to-blade contact is required for the transmission of Labyrinthula in Zostera marina (Burdick et al. 1993). The transmission of Labyrinthula in Thalassia testudinum is considered to be similar to that observed in $Z$. marina, (i.e. by direct contact with infected neighboring blades or with drifting blades containing the pathogen). The consistent presence of infection among clipped $T$. testudinum blades that was observed in this study is not likely to be explained solely by this form of disease transmission. Short, clipped blades should have little contact with one another until they have grown back to sufficient length. Arguably, the possibility of physical 
contact with seagrass tissue containing Labyrinthula is equally likely along the entire length of a clipped blade, not just at the end; yet in our experiment, infection invariably originated and spread from the cut end of blades only. Although Labyrinthula does not require a physical opening in the seagrass blade to gain entrance, it does appear to have an affinity for the clipped ends of $T$. testudinum blades.

What accounts for the consistent infection among clipped blades? A number of possible scenarios can be proposed, although no single explanation clearly explains the occurrence. First, organic matter in the sediment may contain Labyrinthula (Pokorny 1967), providing a nearby source of infection due to the close proximity of the cut ends of clipped shoots to the sediment. Second, infected material could have come into contact with the severed ends of clipped shoots, either via drifting Thalassia testudinum blades carrying the infection or during the clipping manipulation. Lastly, Meyers (1968) noted that Labyrinthula was not uncommon in green, apparently uninfected, blades of T. testudinum. Therefore, it is possible that Labyrinthula may have been present in healthy green tissue near the base of shoots prior to the clipping treatment and became more abundant in damaged tissue decaying in response to injury. Of particular interest, Labyrinthula infection was not observed in clipped blades until 1 mo after the manipulation on May 28, 2002 (Table 1). Laboratory and field experiments in Zostera marina have shown that infection occurs within $48 \mathrm{~h}$ of contact with infected material (Renn 1935, Muehlstein et al. 1988), and Labyrinthula lesions should have been evident at an earlier date on clipped blades if their infection were to begin immediately as a result of clipping. Overall, explaining the consistent occurrence of Labyrinthula infection among clipped $T$. testudinum blades is not readily accomplished from observations in the field, given that several factors may account for the phenomenon.

In summary, the present study demonstrated that the infection of Thalassia testudinum at the SW Florida study site began abruptly during April 2002, rising to levels similar to those observed in Zostera marina during wasting disease events causing seagrass die-off. Yet extensive seagrass mortality due to the infection, as reported in other studies, was not evident. The duration of infection was brief in comparison to other documented infestations of T. testudinum by Labyrinthula, and may represent the natural pattern of infection in healthy populations of $T$. testudinum in the region. Simulated herbivory caused necrotic lesions containing Labyrinthula to form at the severed ends of clipped blades on clipped shoots of $T$. testudinum. However, 3 mo after clipping, levels of infection were not significantly different between simulated herbivory and con- trol plots. It is then inferred that simulated herbivory has no net effect on the extent of Labyrinthula infection in $T$. testudinum in this area. This result does not support the hypothesis of Jackson et al. (2001) that green turtle herbivory decreases disease incidence in T. testudinum. Overall, our results suggest that simulated herbivory did not alter the progression of Labyrinthula infection in $T$. testudinum over the time period in which it persisted in this seagrass system.

Acknowledgements. We thank J. C. Ogden and M. O. Hall for their review of the early stages of the manuscript. Also, we thank A. Adams and D. Porter for invaluable field assistance and technical advice. This work was supported in part by a grant from NSF Biological Oceanography Program (OCE 0337052) and the Department of Education to S.S.B.

\section{LITERATURE CITED}

Bjorndal KA (1980) Nutrition and grazing behavior of the green turtle Chelonia mydas. Mar Biol 56:147-154

Bowles JB (2003) The effect of simulated herbivory and reduced short shoot density on the dynamics of disease in Thalassia testudinum. MSc thesis, University of South Florida, Tampa, FL

Burdick DM, Short FT, Wolf J (1993) An index to monitor the progression of wasting disease in Zostera marina. Mar Ecol Prog Ser 94:83-90

De Jonge VN, Ruiter JF (1996) How subtidal were the 'subtidal beds' of Zostera marina L. before the occurrence of the wasting disease in the early 1930's? Neth J Aquat Ecol 30:99-106

Hily C, Raffin C, Brun A, den Hartog C (2002) Spatiotemporal variability of wasting disease symptoms in eelgrass meadows of Brittany (France). Aquat Bot 72:37-53

Jackson JCB (2001) What was natural in the coastal oceans? Proc Natl Acad Sci USA 98:5411-5418

Jackson JCB, Kirby MX, Berger WH, Bjorndal KA and 15 others (2001) Historical overfishing and the recent collapse of coastal ecosystems. Science 293:629-638

Meyers SP (1968) Observations on the physiological ecology of marine fungi. Bull Misaki Mar Biol Inst Kyoto 12:207-225

Muehlstein LK, Porter D, Short FT (1988) Labyrinthula sp., a marine slime mold producing symptoms of wasting disease in eel grass, Zostera marina. Mar Biol 99:465-472

Muehlstein LK, Porter D, Short FT (1991) Labyrinthula zosterae sp. nov., the causative agent of wasting disease of eelgrass, Zostera marina. Mycologia 83:180-191

Ogden JC (1980) Faunal relationships in Caribbean seagrass beds. In: Phillips RC, McRoy CP (eds) Handbook of seagrass biology: an ecosystem perspective. Garland STPM Press, New York, p 173-198

Peterson HE (1933) Wasting disease of eelgrass (Zostera marina). Nature 132:1004

Pokorny KS (1967) Labyrinthula. J Protozool 14:697-708

Renn CE (1935) A mycetozoan parasite of Zostera marina. Nature 135:544-545

Robblee MB, Barber TR, Carlson PR, Durako MJ and 6 others (1991) Mass mortality of the tropical seagrass Thalassia testudinum in Florida Bay (USA). Mar Ecol Prog Ser 71: 297-299

Short FT, Mathieson AC, Nelson JI (1986) Recurrence of an eelgrass wasting disease on the border of New Hampshire and Maine. Mar Ecol Prog Ser 29:89-92 
Short FT, Muehlstein LK, Porter D (1987) Eelgrass wasting disease: cause and recurrence of a marine epidemic. Biol Bull (Woods Hole) 173:557-562

Taylor WR (1933) Epidemic among Zostera colonies. Rhodora 35:186

Thayer GW, Engel DW, Bjorndal KA (1982) Evidence for the short-circuiting of the detritus cycle of seagrass beds by the green turtle, Chelonia mydas. J Exp Mar Biol 62:173-183

Tomasko DA, Dawes CJ (1989) Evidence for the physiological integration between shaded and unshaded short shoots of Thalassia testudinum. Mar Ecol Prog Ser 54:299-305

Tomlinson PB (1974) Vegetative morphology and meristem dependence-foundation of productivity in seagrasses.

Editorial responsibility: Victor de Jonge (Contributing Editor), Haren, The Netherlands
Aquaculture 4:107-130

Williams SL (1988) Thalassia testudinum productivity and grazing by green turtles in a highly disturbed seagrass bed. Mar Biol 98:447-455

Young EL (1943) Studies on the etiologic agent of the wasting disease of eel grass. Am J Bot 30:586-593

Zieman JC (1976) The ecological effects of physical damage from motor boats on turtle grass beds in southern Florida. Aquat Bot 2:127-139

Zieman JC, Fourqurean JW, Frankovich TA (1999) Seagrass die-off in Florida Bay: long-term trends in abundance and growth of turtle grass, Thalassia testudinum. Estuaries 22: $460-470$

Submitted: April 2, 2004; Accepted: August 12, 2004

Proofs received from author(s): November 23, 2004 